\title{
The first Mainland China monetary judgment enforced in NSW Australia: Bao v Qu; Tian (No 2) [2020] NSWSC 588
}

by Jie (Jeanne) Huang, Sydney Law School

On 19 May 2020, the Supreme Court of New South Wales rendered the judgment in Bao v Qu; Tian (No 2) and decided to enforce a monetary judgment issued by the Qingdao Intermediate People's Court of Shanghai Province, China. This is the first case at the state of NSW in Australia where a Chinese monetary judgment got enforced.

\section{The Chinese judgment-rendering proceedings}

Both plaintiff and the defendants are citizens of China. The two defendants were a couple. The defendants allegedly did not pay loans borrowed from the plaintiff. In 2014, the People's Court of Laoshan District Qingdao handed down the firstinstance judgment for the plaintiff. One defendant appealed. Both defendants were represented in the second-instance trial at the Qingdao Intermediate People's Court of Shangdong Province ('Qingdao Court'). The Qingdao Court rendered the final judgment ('Chinese judgment') ordering the defendants to pay RMB 2,050,000 plus interest to the plaintiff in 2015. The Chinese judgment was partly enforced in China but largely remained outstanding.

\section{The NSW judgment-enforcement proceedings}

The plaintiff applied to enforce the Chinese judgment at the Supreme Court of NSW in 2019 under the common law. The defendants are resident in NSW and were personally served with the court proceedings.

The defendants conceded that the Qingdao Court had jurisdiction, the Chinese judgment was final and conclusive, and they were judgment debtors. However, they alleged that a substantial amount of money had been returned to the plaintiff 
before the Chinese judgment was rendered. The plaintiff rejected this argument alleging that the defense went to the merits of the Chinese judgment that should not be reviewed by the NSW court at the judgment recognition and enforcement ('JRE') proceedings.

The NSW court holds that defendants submitted to the jurisdiction of Chinese court by their procedural conducts. There is no evidence of any step taken to challenge the Chinese judgment in China. The first issue at the NSW proceeding is whether the Chinese judgment is obtained by fraud. Namely, whether the Chinese court was intentionally or recklessly misled into determining the incorrect value of the debt by not being made aware of the alleged repayments. The NSW court held that one of the alleged repayments seemed to have been raised in the Chinese proceedings but ultimately rejected by the Chinese Court. No evidence showed that Chinese Court denied the defendants the opportunity to presenting their case before an impartial tribunal or that the defendants were otherwise not given due notice. There was also no evidence showing that the alleged repayments were not reasonably discoverable at the time of the Chinese proceedings. Further, nothing proved that the alleged repayments had ever occurred or were related to the loans decided in the Chinese judgment. In conclusion, NSW court rejected the alleged repayments and refused to review the merits of Chinese judgment.

The second issue focuses on the legal nature of the punitive interest awarded in the Chinese judgment. The Chinese judgment included two types of interests. The first is the general interest calculated at the 'benchmark interest rate for the loans in the same type as issued by the People's Bank of China for the same period'. The second is the punitive interest awarded according to Article 253 of Chinese Civil Procedural Law, being that 'if the judgment debt was not satisfied by 20 September 2015, then "the interest on the debt during the period of delay in fulfillment shall be paid at the double amount".' The court held that no submissions were made that the imposition of Article 253 interest was penal in nature, so it should be awarded.

\section{Comments}

\section{Reciprocity}

China is not listed in the Foreign Judgments Act 1991 (cth), so Chinese judgments 
cannot benefit from the ex parte registration process. Nevertheless, Chinese judgments can be recognized and enforced under the common law in Australia. However, China requires de facto reciprocity. This is demonstrated by a reply issued by the Chinese Supreme People's Court in 2006, which provides that judgments issued in Australia cannot be recognized and enforced in China because Australia has not offered reciprocity to Chinese judgments.[1] Liu v Ma \& anor [2017] VSC 810 is the first Chinese monetary judgment recognized and enforced in the state of Victoria. By Bao, the NSW court also enforced a Chinese monetary judgment. Considering the recent JRE development in Australia, Chinese Supreme People's Court should review the 2006 reply. De facto reciprocity should have been established between China and Australia (or at least the states of Victoria and NSW). Judgments issued in Australia should be recognized and enforced in China if they do not violate the basic principles of Chinese law and the sovereignty, security and public interest of China according to Article 282 of Chinese Civil Procedure Law.

\section{The alleged repayment}

According to the NSW court, the Chinese judgment indicates that the Chinese court 'refuse[d] to consider this request [to reduce the judgment debt as a result of the alleged repayment of RMB 200,000]' because this claim 'exceeded the scope of the Appellant's claim'. The Chinese court's rejection does not violate natural justice. This is because according to Chinese Civil Procedure Law, an appeal should be brought within 15 days after the first-instance judgment is served. If a party fails to bring a claim within this time period, the party loses its right to appeal. In practice, some appellants may bring an appeal within the time limit without clearly listing the claims and later try to add new claims. This practice goes against the seriousness of appeal. It is also inconsistent with the fairness and efficiency of litigation because the respondent should be served with the new claim and given a reasonable time to prepare the defence. Therefore, as a general principle, Chinese courts do not consider a new claim if it is not raised in the appeal petition.[2]

\section{Double interest}

Australian courts do not enforce foreign punitive damages that aim to 'penalise the [ ] defendant and to deter others from failing to comply with the Court's orders' (Schnabel v Lui [2002] NSWSC 15 at [176]). However, the courts can 
enforce punitive damages that were to compensate the plaintiff's private right due to the defendant's deliberate and callous conduct and involved no public connotation in the remedy (Benefit Strategies Group v Prider [2004] SASC 365 at [72]).

Article 253 of the Chinese Civil Procedure Law provides that if the party against whom enforcement is sought fails to pay money within the period specified in the judgment, he or she shall pay double interest for the debt for the period of delayed performance.'

The double interest imposed by this provision intends to punish the defendant for the delay of executing the judgment and remedy the plaintiff's private right. It is not for the public interest of Chinese state. Therefore, the court correctly decided that the double interest should be enforced at the NSW.

[1] Letter of Reply of the Supreme People's Court on Request for Instructions Re Application of DNT France Power Engine Co., Ltd. for Recognition and Enforcement of Australian Court Judgment [2006] Min Si Ta Zi No 45.

[2] There are few exceptions to this general principle. For example, the respondent agrees to add the new claim to the trial, or the new claim involves a fact which must be investigated by the court rather than the parties and without the finding of this fact, the case cannot be correctly decided. 